\title{
KINERJA GURU SEJARAH SMA DI KOTA METRO
}

\author{
Kuswono, S.Pd., M.Pd. \\ Pendidikan Sejarah Universitas Muhammadiyah Metro \\ kromowijoyo@gmail.com
}

\begin{abstract}
Abstrak
Tujuan penelitian ini adalah untuk mendeskripsikan mengenai kinerja guru Sejarah SMA di Kota Metro. Menilai unjuk kerja guru sejarah di kota Metro Sebagai infromasi untuk langkah-langkah pengembangan kinerja guru sejarah dalam menyongsong kurikulum 2013. Jenis penelitian ini adalah kuantitatif deskriptif dengan memakai metode survei. Penelitian ini akan mengkaji mengenai kinerja guru dengan populasi seluruh guru sejarah di SMA Kota Metro. Teknik pengambilan sampel menggunakan disproportionate stratified random sampling, teknik pengumpulan data menggunakan angket dengan menggunakan skala Likert. Skor maksimal kinerja guru yakni 7 sehingga dapat dibandingkan dengan skor yang diperoleh dari tiap sekolah yakni SMA 1 Metro mendapatkan nilai 6,59. SMAN 2 Metro mendapatkan skor 6, 17. SMAN 3 Metro mempunyai skor 4,03. SMAN 4 mendapatkan skor 5,33. SMAN 5 mendapatkan skor 6,61 dan SMAN 6 mendapatkan skor 5,91. Kinerja guru sejarah SMA Negeri di Kota Metro berada pada level baik.

Kata kunci: kinerja guru, pembelajaran sejarah
\end{abstract}

\section{Abstract}

The aim of this study was to describe the performance of high school history teacher in Metro City. Assess teacher performance in the history of the city's Metro As infromasi for measures of performance development in the history teachers to meet curriculum of 2013. This type of research is quantitative descriptive using the survey method. This study will assess the performance of teachers and the entire population of high school history teacher in Metro City. The sampling technique using disproportionate stratified random sampling, data collection techniques using a questionnaire using Likert scale. The maximum score 7 so that teacher performance can be compared with scores obtained from each school that SMA 1 Metro get the value of 6.59. SMAN 2 Metro get a score of 6, 17. SMAN 3 Metro has a score of 4.03. SMAN 4 get a score of 5.33. SMAN 5 get a score of 6.61 and SMAN 6 get a score of 5.91 . Performance history teacher high schools in Metro City is at a good level.

Keywords: teacher performance, learning the history

\section{PENDAHULUAN}

$\begin{array}{ll}\text { Keberhasilan tujuan pendidikan } \\ \text { (output), sangat ditentukan oleh } \\ \text { implementasinya } & \text { (proses), dan }\end{array}$
implementasinya sangat dipengaruhi oleh tingkat kesiapan segala hal (input) yang diperlukan untuk berlangsungnya implementasi. Sekolah sebagai sistem tersusun dari komponen konteks, input, proses, output, dan outcome (Slamet, 2005). Tahap proses merupakan tahap pelaksanaan pembelajaran yang dipengaruhi oleh kinerja seorang guru. Penilaian kinerja memungkinkan guru dapat melaksanakan pekerjaannya secara profesional, bukan hanya untuk kepentingan guru, namun juga untuk pengembangan peserta didik dan demi masa depan bangsa Indonesia.

Kinerja guru di dalam kelas adalah nyawa dari perusahaan pendidikan. Guru harus mengkombinasikan pengetahuan, keterampilan dan kemampuan menjadi kompetensi kinerja spesifik yang menjadi 
pendorong belajar siswa dan prestasi. Dengan demikian sistem atau proses untuk mengukur mengajar telah semakin diakui sebagai bagian penting dari peningkatan puzzle instruksional.

Penilaian kinerja mengajar adalah bagian penting dari setiap upaya untuk mengembangkan sistem yang koheren untuk manajemen strategis sumber daya manusia guru. Penilaian seperti menyediakan baik ukuran seberapa baik kita mencapai manajemen tersebut, dan merupakan bagian dari sistem manajemen itu sendiri.

Kompetensi kinerja guru yang membentuk dasar untuk mengukur kinerja mengajar dapat diidentifikasi melalui kombinasi penelitian dan penilaian ahli. Selain itu, kompetensi dapat dilemparkan ke dalam kinerja model kompetensi guru formal. Model kompetensi kinerja menggambarkan representasi yang luas dari perilaku guru yang dianggap diinginkan untuk instruksi kelas yang efektif. Biasanya model kompetensi menentukan domain kinerja utama, dan dalam setiap domain adalah perilaku tertentu (Milanowski, 2009).

Kinerja guru tidak hanya ditunjukkan berupa hasil kerja, akan tetapi termasuk perilaku kerja. Kinerja guru merupakan hasil kerja secara nyata yang ditunjukkan oleh individu sebagai upaya yang dilakukan dalam menyelesaikan pekerjaan untuk menghasilkan keluaran dalam periode tertentu. Lebih lanjut Nurhayati dalam penelitiannya mengemukakan bahwa faktor-faktor pendukung kinerja guru yakni factor kesejahteraan guru, faktor pola kepemimpinan kepala sekolah dan faktor motivasi guru dalam mengajar (Nurhayati, 2006).

Kinerja guru (teacher performance) berkaitan dengan kompetensi guru, artinya untuk memiliki kinerja yang baik guru harus didukung dengan kompetensi yang baik. Tanpa memiliki kompetensi yang baik seorang guru tidak akan mungkin dapat memiliki kinerja yang baik.

Sebaliknya, seorang guru yang memiliki kompetensi yang baik belum tentu memiliki kinerja yang baik. Kinerja guru sama dengan kompetensi plus motivasi untuk menunaikan tugas dan motivasi untuk berkembang. Oleh karena itu, kinerja guru merupakan perwujudan kompetensi guru yang mencakup kemampuan dan motivasi untuk menyelesaikan tugas dan motivasi untuk berkembang (S. Eko Putro Widoyoko dan Anita Rinawati, 2012).

Kelas yang baik tidak cukup hanya didukung oleh perencanaan pembelajaran, kemampuan guru mengembangkan proses pembelajaran serta penguasaannya terhadap bahan ajar dan juga tidak cukup dengan kemampuan guru dalam menguasai kelas tanpa diimbangi dengan kemampuan melakukan evaluasi terhadap pencapaian kompetensi siswa (Said Hamid Hasan, 2011). 
Ukuran lain kualitas guru memiliki efek pada prestasi siswa atau peringkat dari pengajaran di kelas guru, mengukur kinerja guru memberikan solusi yang menjanjikan dan praktis. Ukuran kinerja guru harus menjadi keduanya cukup komprehensif untuk menangkap esensi dari pengajaran yang baik, dan juga menyediakan untuk metrik akuntabilitas prestasi siswa masyarakat dapat mudah memahami (John Schacter, 2012).

Guru sejarah yang tidak mempunyai kinerja baik menyebabkan pembelajaran sejarah kurang berhasil dalam menyampaikan nilai penghayatan yang terkandung dalam materi. Faktor guru dalam pembelajaran sejarah menjadi hal yang penting untuk keberhasilan pembalajaran sejarah. Kompetensi guru sejarah SMA meliputi penguasaan bidang studi atau bahan ajar, pemahaman karakteristik peserta didik, penguasaan pengelolaan pembelajaran, penguasaan strategi dan metode pembalajaran, penguasaan penilaian hasil belajar siswa dan memiliki kepribadian dan wawasan pegembangan profesi (Aman, 2011).

\section{METODE PENELITIAN}

Lokasi penelitian yakni seluruh SMA Negeri di Kota Metro. Penelitian ini menggunakan kuantitatif deskriptif dengan metode survei. Kuantitatif deskriptif bertujuan untuk menjabarkan, menguraikan, dan menafsirkan kondisi peristiwa yang sedang terjadi dalam konteks permasalahan yang ada di lapangan berdasarkan data yang diperoleh secara kuantitatif. Teknik pengambilan sampel menggunakan disproportionate stratified random sampling dengan alasan bahwa populasi berstrata dan kurang proporsional.

Angket dalam penelitian ini dibagi menjadi beberapa indikator yang merupakan tujuh sub-variabel kinerja guru sejarah. Sub-variabel tersebut adalah keterampilan guru sejarah dalam pembukaan pembelajaran, penguasaan konsep sejarah (materi sejarah yang disampaikan), memahami karaketeristik siswa, penguasaan keterampilan dalam pengelolaan kelas, evaluasi pembelajaran sejarah dan penanaman karaketer dalam pembelajaran.

Sub-variabel pada angket kinerja guru sejarah tersebut di atas tersebar pada 35 item pernyataan. Angket tersebut diujicobakan di SMA Kartikatama Kota Metro untuk diuji validitas dan realibilitasnya. Ujicoba tersebut melibatkan 67 siswa. Mengacu pada uji kriteria validitas maka ditetapkan bahwa angket dinyatakan valid apabila korelasinya $(r)>0,300 \quad$ (S. Eko Putro Widoyoko, 2012). Setelah dilakukan tes validitas dan reliabilitas dengan mengunakan SPSS maka terdapat beberapa item angket yang tidak memenuhi kriteria minimal. Item pernyataan yang tidak valid tersebut adalah nomor 20, 22, 25, 34 sehingga tidak bisa digunakan untuk dijadikan sebagai pengukuran dalam angket kinerja ini. Sesuai dengan hasil ujicoba dan 
beberapa pertimbangan dari validator maka peneliti memutuskan untuk merevisi angket menjadi hanya 31 item dengan $r>0,3000$ dan reliabilitas Cronbach sebesar 0,938 .

\section{PEMBAHASAN}

Kinerja Guru Sejarah SMA di Kota Metro

Hasil tabulasi dan analisis data mengenai kinerja guru sejarah SMA di Kota Metro adalah sebagai berikut di bawah ini.

Tabel. Kinerja Guru Sejarah SMA Negeri di Kota Metro

\begin{tabular}{|c|c|c|c|c|c|c|c|}
\hline \multirow{2}{*}{$\begin{array}{c}\text { SUB- } \\
\text { VARIABEL }\end{array}$} & \multicolumn{6}{|c|}{ NAMA SEKOLAH (SMAN DI METRO) } & \multirow[t]{2}{*}{ JUMLAH } \\
\hline & $\begin{array}{c}\text { SMAN } \\
1\end{array}$ & $\begin{array}{c}\text { SMAN } \\
2\end{array}$ & $\begin{array}{c}\text { SMAN } \\
3\end{array}$ & $\begin{array}{c}\text { SMAN } \\
4\end{array}$ & $\begin{array}{l}\text { SMAN } \\
5\end{array}$ & $\begin{array}{c}\text { SMAN } \\
6\end{array}$ & \\
\hline $\begin{array}{l}\text { Membuka } \\
\text { pelajaran }\end{array}$ & 0.93 & 0.92 & 0.66 & 0.85 & 0.98 & 0.95 & 5.29 \\
\hline $\begin{array}{l}\text { Konsep } \\
\text { sejarah }\end{array}$ & 0.96 & 0.86 & 0.53 & 0.85 & 0.91 & 0.84 & 4.94 \\
\hline $\begin{array}{l}\text { Karakteristik } \\
\text { siswa }\end{array}$ & 0.97 & 0.94 & 0.60 & 0.84 & 0.96 & 0.89 & 5.20 \\
\hline $\begin{array}{l}\text { Pengelolaan } \\
\text { pembelajaran }\end{array}$ & 0.95 & 0.88 & 0.52 & 0.74 & 0.93 & 0.86 & 4.88 \\
\hline $\begin{array}{l}\text { Penguasaan } \\
\text { strategi }\end{array}$ & 0.90 & 0.83 & 0.47 & 0.69 & 0.91 & 0.81 & 4.63 \\
\hline Evaluasi & 0.94 & 0.85 & 0.66 & 0.62 & 0.96 & 0.67 & 4.70 \\
\hline $\begin{array}{l}\text { Penanaman } \\
\text { Karakter }\end{array}$ & 0.94 & 0.88 & 0.59 & 0.75 & 0.96 & 0.89 & 5.00 \\
\hline Jumlah & 6.59 & 6.17 & 4.03 & 5.33 & 6.61 & 5.91 & 34.63 \\
\hline
\end{tabular}

Dari tabel di atas dapat dijelaskan bahwa kinerja guru sejarah di SMAN 1 Metro sangat baik, hal ini terlihat dari skor masing-masing sub-variabel yakni membuka pelajaran dengan skor 0.93, konsep sejarah 0.96, pemahaman karakteristik siswa 0.97 , pengelolaan pembelajaran, 0.95 , penguasaan strategi 0.90, evaluasi pembelajaran 0.94 dan penanaman karakter dengan skor 0.94. Tidak jauh berbeda dengan SMA Negeri 1 Metro, kinerja guru sejarah SMA Negeri 2
Metro juga sangat baik, dari tabel di atas tiap sub-variabel menunjukkan skor yang tinggi yakni, membuka pelajaran 0.92 , penguasaan konsep sejarah 0.86 , pemahaman karakteristik siswa 0.94, pengelolaan pembelajaran 0.88 , penguasaan strategi 0.83 , evaluasi pembelajaran 0.85 , dan kemampuan menanamkan karakter 0.88 .

Berbeda dengan SMA Negeri 1 dan SMA Negeri 2 kota Metro, SMA Negeri 3 Metro kinerja guru sejarahnya masih banyak 
kelemahan dikarenakan masih ada beberapa sub-variabel yang berkategori cukup. Hal ini dapat dilihat pada tabel di atas dengan rincian sebagai berikut: kemampuan membuka pelajaran dengan skor $0.66=$ baik, penguasaan konsep sejarah $0.53=$ cukup, pemahaman karakteristik siswa $0.60=$ cukup, pengelolaan pembelajaran 0.52 = cukup, penguasaan strategi pembelajaran $0.47=$ cukup, evaluasi pembelajaran $0.66=$ baik, dan penanaman karakter $0.59=$ cukup.

Meski kinerja guru sejarah SMA Negeri 4 Metro tak sebagus SMA Negeri 1 dan 2 Metro, berdasarkan analisis, kinerja guru di sekolah ini dalam sebagian subvariabel mendapatkan kategori sangat baik dan sebagian lagi berkategori baik. Yakni kemampuan membuka pelajaran dengan skor $0.85=$ sangat baik, penguasaan konsep sejarah $0.85=$ sangat baik, pemahaman karakteristik siswa 0.84 = sangat baik, pengelolaan pembelajaran $0.79=$ baik, penguasaan strategi pembelajaran $0.69=$ baik, evaluasi pembelajaran $0.62=$ baik, dan penanaman karakter $0.75=$ baik .

Kinerja guru sejarah di SMA Negeri 5 Metro berdasarkan analisis mendapatkan kategori sangat baik dalam semua sub-variabel yakni kemampuan membuka pelajaran dengan skor $0.98=$ sangat baik, penguasaan konsep sejarah $0.91=$ sangat baik, pemahaman karakteristik siswa 0.86 = sangat baik, pengelolaan pembelajaran 0.93 = sangat baik, penguasaan strategi pembelajaran 0.91 = sangat baik, evaluasi pembelajaran 0.96 = sangat baik, dan penanaman karakter 0.96 = sangat baik .

Berdasarkan data pada tabel di atas untuk SMA Negeri 6 Metro hampir seluruh sub-variabel mendapat kategori sangat baik, hanya ada satu variabel yang mendapatkan kategori baik yaitu dalam evaluasi pembelajaran mendapat skor 0.67. Untuk sub-variabel yang memperoleh kategori sangat baik meliputi kemampuan membuka pelajaran dengan skor $0.95=$ sangat baik, penguasaan konsep sejarah $0.84=$ sangat baik, pemahaman karakteristik siswa 0.89 = sangat baik, pengelolaan pembelajaran 0.86 = sangat baik, penguasaan strategi pembelajaran 0.81 = sangat baik, dan penanaman karakter 0.89 = sangat baik . Sehingga dapat disimpulkan kinerja guru sejarah di SMA Negeri 6 Metro sudah sangat baik.

\section{Kinerja Guru Sejarah dalam Membuka Pelajaran}

Sub-variabel dari kinerja guru sejarah yang pertama adalah keterampilan guru dalam membuka pembelajaran. Pada diagram di atas terlihat bahwa guru dari keenam SMA Negeri di kota Metro memiliki kemampuan membuka pelajaran yang berbeda yakni, SMA Negeri 1 Metro dengan skor 0.93, SMA Negeri 2 Metro 0.92, SMA Negeri 3 Metro 0.66, SMA 
Negeri 4 Metro 0.85, SMA Negeri 5 Metro 0.98, dan SMA Negeri 6 Metro memperoleh skor 0.95. Data tersebut dapat dipersentasekan dengan mengalikan 100 untuk masing-masing skor, sehingga akan diperoleh SMA Negeri 1 Metro 93\%, SMA Negeri 2 Metro 92\%, SMA Negeri 3 Metro 66\%, SMA Negeri 4 Metro 85\%, SMA Negeri 5 Metro 98\%, dan SMA Negeri 6 Metro 95\%. Sebagian besar guru sejarah sudah membuka pelajaran dengan sangat baik, hanya sebagian yang berpredikat baik yakni SMA Negeri 3 Metro.

\section{Penguasaan Konsep Sejarah}

Sub-variabel kedua dari kinerja guru sejarah adalah penguasaan konsep sejarah. Pada diagram di atas terlihat SMA Negeri 1 Metro dengan skor $0.96=$ 96\%, SMA Negeri 2 Metro $0.86=86 \%$, SMA Negeri 3 Metro $0.53=53 \%$, SMA Negeri 4 Metro $0.85=85 \%$, SMA Negeri 5 Metro $0.91=91 \%$, dan SMA Negeri 6 Metro 0.84 $=84 \%$. Berdasarkan hasil analisis di atas, diketahui bahwa penguasaan konsep sejarah guru SMA Negeri 1, 2, 4, 5, dan 6 Metro dalam kategori sangat baik, sedangkan untuk SMA Negeri 3 Metro dalam kategori cukup.

\section{Pemahaman Karakteristik Siswa}

Sub-variabel ketiga dari kinerja guru sejarah adalah pemahaman karakteristik siswa. Berdasarkan diagram di atas, menunjukkan bahwa hampir seluruh guru sejarah memahami karaktristik siswa dengan kategori sangat baik, SMA Negeri 1 Metro dengan skor
$0.97=97 \%$, SMA Negeri 2 Metro 0,94= 94\%, SMA Negeri 4 Metro 0,84 = 84\%, SMA Negeri 5 Metro $0.96=96 \%$, dan SMA Negeri 6 Metro $0.89=86 \%$. Hanya SMA Negeri 3 Metro yang medapat kategori baik dengan skor $0.60=60 \%$.

Kinerja Guru Sejarah Ditinjau dari Penguasaan Strategi Mengajar

Sub-variabel berikutnya dari kinerja guru sejarah adalah penguasaan strategi pembelajaran. Hal ini terlihat SMA Negeri 1 Metro dengan skor $0.90=$ 90\%, SMA Negeri 2 Metro 0,83 = 83\%, SMA Negeri $30.47=47 \%$, SMA Negeri 4 Metro $0,69=69 \%$, SMA Negeri 5 Metro $0.91=$ 91\% dan SMA Negeri 6 Metro $0.81=81 \%$. dari diagram di atas diketahui bahwa guru di empat SMA Negeri telah menguasai strategi pembelajaran dengan sangat baik yakni SMA Negeri 1, 2, 5, dan 6 kota Metro. Sedangkan SMA Negeri 3 kota Metro dalam kategori cukup dan SMA Negeri 4 Kota Metro dalam Kategori baik.

\section{Pengelolaan Pembelajaran Sejarah}

Sub-variabel berikutnya dari kinerja guru sejarah adalah pengelolaan pembelajaran sejarah. Dari diagram di atas diketahui bahwa, SMA Negeri 1 Metro dengan skor $0.95=95 \%$, SMA Negeri 2 Metro $0,88=88 \%$, SMA Negeri $30.52=$ $52 \%$, SMA Negeri 4 Metro 0,74 = 74\%, SMA Negeri 5 Metro $0.93=93 \%$, dan SMA Negeri 6 Metro 0.86=86\%. Seperti sub-variabel sebelumnya pada sub varibel ini terlihat guru sejarah di empat SMA Negeri kota Metro dapat mengelola pembelajaran 
dengan sangat baik, yakni SMA Negeri 1, 2, 5, dan 6 kota Metro. Sekolah yang berkategori baik adalah SMA Negeri 4 Metro dan sekolah berkategori cukup dalam pengelolaan pembalajaran adalah SMA Negeri 3 Metro.

\section{Kinerja Guru dalam Evaluasi}

Pembelajaran Sejarah

Sub-variabel berikutnya dari kinerja guru sejarah adalah evaluasi pembelajaran. Pada diagram di atas terlihat hanya separuh guru sejarah SMA Negeri di kota Metro yang telah menguasai evaluasi pembelajaran dengan kategori sangat baik yakni SMA Negeri 1 Metro dengan skor $0.94=94 \%$, SMA Negeri 2 Metro 0,85 = 85\%, dan SMA Negeri 5 Metro yakni $0.96=96 \%$. Sedangkan tiga SMA Negeri lainnya dengan kategori baik meliputi,SMA Negeri $30.66=66 \%$, SMA Negeri 4 Metro 0,62 = $62 \%$, SMA Negeri 6 Metro $0.67=67 \%$.

\section{Kinerja Guru dalam Penanaman Karakter}

Sub-variabel terakhir dari kinerja guru sejarah adalah penanaman karakter. pada diagram di atas terihat sebagian besar guru sejarah SMA Negeri di kota Metro telah menanamkan karakter pada siswa dalam pembelajaran sejarah, SMA Negeri 1 Metro dengan skor $0.94=94 \%$, SMA Negeri 2 Metro $0,88=88 \%$, SMA Negeri $30.59=59 \%$, SMA Negeri 4 Metro $0,75=75 \%$, SMA Negeri 5 Metro $0.96=$ 96\% dan SMA Negeri 6 Metro $0.89=89 \%$. berdasarkan diagram di atas diketahui bahwa SMA Negeri 1, 2, 5, dan 6 kota Metro telah menanamkan karakter dengan kategori sangat baik, SMA Negeri 3 kota Metro dengan kategori cukup dan SMA Negeri 4 kota Metro dengan kategori baik.

\section{SIMPULAN}

Hasil penelitian ini menunjukan bahwa kinerja guru sejarah di kota Metro rata-rata mencapai kategori baik dan sangat baik. Namun dari analisis yang telah dilakukan serta temuan-temuan dalam penelitian yang dilihat dari beberapa sub-variabel dan indikator kinerja guru maka terdapat beberapa hal yang menunjukan kelemahan-kelemahan kinerja guru sejarah. sub-variabel tersebut antara lain tentang evaluasi pembelajaran sejarah dan rata-rata guru belum mempunyai bahan ajar untuk mendukung terhadap implementasi pembelajaran sejarah berkarakter.

\section{Daftar Pustaka}

Aman. 2011. Model Evaluasi Proses dalam pembelajaran Sejarah. Yogyakarta: Ombak

Hasan, Said Hamid. 2011. Bahan Ajar Pengembangan Asesmen Kinerja dan Portofolio dalam Pembelajaran Sejarah (Tulisan untuk peringan 70 tahun Prof. Dr. Asmawi Zainul, M.Ed). Bandung: UPI.

Milanowski, Anthony T. 2009. Review of Teaching Performance Assessments for Use in Human Capital Management. University of Wisconsin-Madison.

Nurhayati B. "Faktor-Faktor yang Mempengaruhi Profesionalisme dan Kinerja Guru Biologi di SMAN Kota 
Makassar Sulawesi Selatan". Mimbar Pendidikan. No. 4/XXV/2006. Universitas Pendidikan Indonesia.

Schacter, John. 2010. Teacher Performance-Based Accountability: Why, What and How. Milken Family Foundation Santa Monica, CA.

Widoyoko, S. Eko Putro dan Rinawati, Anita. "Pengaruh Kinerja Guru terhadap Motivasi Belajar Siswa." Cakrawala Pendidikan. Juni 2012. Th. XXXI. No. 2. LPPM UNY. 